https://helda.helsinki.fi

\title{
Assessment of competences in knowledge work and object-bound collaboration during higher education courses
}

\section{Muukkonen, Hanni}

Routledge - Taylor \& Francis Group

2017

Muukkonen , H , Lakkala , M , Toom , A \& Ilomäki , L 2017 , Assessment of competences in knowledge work and object-bound collaboration during higher education courses . in E Kyndt , V Donche , K Trigwell \& S Lindblom-Ylänne (eds), Higher Education Transitions : Theory and Research . New Perspectives on Learning and Instruction, Routledge - Taylor \& Francis Group, Abingdon, Oxon , pp. 288-305 .

http://hdl.handle.net/10138/311062

unspecified

acceptedVersion

Downloaded from Helda, University of Helsinki institutional repository.

This is an electronic reprint of the original article.

This reprint may differ from the original in pagination and typographic detail.

Please cite the original version. 


\title{
Assessment of competences in knowledge work and object-bound collaboration during higher education courses
}

Hanni Muukkonen, Minna Lakkala, Auli Toom \& Liisa Ilomäki, University of Helsinki, Finland

\begin{abstract}
The chapter addresses collaborative dimensions of generic competences promoted by complex and openended assignments in higher education. The study investigated students' knowledge work competence development within fourteen courses in the domains of media engineering and life sciences by utilising the Collaborative Knowledge Practices questionnaire. A comparison of findings on students' self-assessed and lecturer-assessed competence-development generated evidence of lecturers expecting and claiming more learning had taken place than the students. The intensity of activities and type of assignments had an impact on the competence-learning students reported. The questionnaire provides feedback on competence-development independently from disciplinary content and comparably across courses.
\end{abstract}

\section{Introduction}

Current university education faces challenges in meeting the requirements of society to provide students with the necessary competences for changing work life practices, such as solving openended problems, collaborative creativity, agency, and digital competences (Broussard, La Lopa, \& Ross-Davis 2007; Klusek \& Bernstein 2006; Muukkonen \& Lakkala 2009; Halpern 2014). According to OECD (2013a), higher education is expected to provide competences for critical

Muukkonen, H., Lakkala, M. Toom, A., \& Ilomäki, L. (2017). Assessment of competences in knowledge work and object-bound collaboration during higher education courses. In E. Kyndt, V. Donche, K. Trigwell, \& S. Lindblom-Ylänne (Eds.) Higher Education Transitions: Theory and Research (pp. 288305). EARLI book series New Perspectives on Learning and Instruction. 
thinking, discipline knowledge, problem solving, teamwork, communication, professional skills, ethics and values, creativity and learning to learn. These competences are extremely important for students to work in continuously changing working life contexts and be prepared to act effectively in their future professions. Knowledge work in society is work that focuses on advancing knowledge objects (e.g., project plans, prototypes, articles) by a community's collective efforts and resources (Bereiter 2002; Hakkarainen, Palonen, Paavola, \& Lehtinen 2004). The term epistemic or knowledge object has been used to refer to entities or effect that for the most part are unknown and can be studied (Knorr Cetina 2001; Rheinberger 1997), for instance water shortages or the ecological use of natural resources. Epistemic objects are of interest because they represent the types of uncertainty and incompleteness present in evolving work practices, where multiple interpretations of knowledge and practices co-exist and are being created. Furthermore, this is typically work that requires a higher education background and involves the rich use of digital technologies (Nätti, Anttila, \& Tammelin 2012). Still, these types of knowledge practices are sometimes overlooked in the pedagogical methods of university education, although they are central to the research practices of these organizations.

Kember (2009) showed that students' various competences developed if the curriculum made demands on them to practice the use of these capabilities, e.g., communication and teamwork skills developed through group projects and activities in which communication was practiced. Teaching how to work with complex challenges in interdisciplinary teams is considered important, but often more difficult to realize than teaching specific knowledge and skills, especially within undergraduate programs with high annual intakes of students. Also, the 
definition and assessment of competences in collaborative knowledge creation follows a different logic to those used in the tradition of assessing individual knowledge and skills.

To extend on scarce existing prior research, our work clarifies the definition of knowledge work competences, suggests how to nurture them through certain educational practices in $\mathrm{HE}$ and describes an instrument for assessing their development in a contextually sensitive way. We have developed the Collaborative Knowledge Practices Questionnaire (CKP; Muukkonen et al. 2016) that focuses on the inter-individual, interdisciplinary, and technology-mediated nature of knowledge work, relevant both from the viewpoint of higher education and working life (e.g., Banta \& Pike 2012). The CKP questionnaire builds on the knowledge creation metaphor of learning and six design principles representing corresponding practices (Paavola et al. 2011). Findings from series of case studies on collaborative technology-mediated learning in HE (e.g., Damşa, Kirschner, Andriessen, Erkens, \& Sins 2010; Jalonen, Lakkala, \& Paavola 2011; Kosonen, Muukkonen, Lakkala, \& Paavola 2012; Karlgren, 2012; Lakkala, Muukkonen, Paavola, \& Hakkarainen 2008; Muukkonen, Lakkala, \& Hakkarainen 2005; Muukkonen \& Lakkala 2009) form the empirical grounding for our questionnaire development and investigation. The questionnaire is intended as a tool for students' self-evaluation of knowledge work competences, and course development purposes.

The study's main empirical aim was to investigate students' knowledge work competence development within specific courses in the domains of media engineering and life sciences by 
utilising the CKP questionnaire. Both the students' and the teachers' perceptions of the students' competence development during the courses are explored.

\section{Defining and assessing domain-general knowledge work competences}

Prior research has often made a distinction between learning of domain-general (generic) problem solving competences and domain-specific factual knowledge and problem-solving strategies (e.g., Greiff et al. 2014). The domain-general competences are more challenging for assessment frames (Shavelson 2010), whereas the domain-specific knowledge, skills and expertlike thinking are more readily definable based on the criteria and standards of a given profession or domain. Often within educational assessment settings, problem-solving situations are considered to be specified problem-solving tasks that are carried out individually. However, during complex, authentic activities, domain-specific and domain-general competences tend to be needed and utilized in an intertwined manner to produce novel ideas, syntheses, designs or practices. Furthermore, the agentic role of students should be understood broadly: individual students are not working alone but within teams working with other teams, teachers, and possibly external experts. It has been suggested that in order to assess the development of such generic competences, students should produce divergent and open-ended outcomes during the educational activities (Sadler 2009; Strijbos, Engel, \& Struyven 2015). In line with this proposal, our work focuses on specifying some of the domain-general aspects related to collaborative knowledge creation, i.e., work on open-ended complex assignments in higher education. 
A recent review (Strijbos et al. 2015) of bachelor level generic competences proposed grouping them into three clusters: conceptual, people, and personal skills. These, however, involve complex interconnections. Based on the prior work of Young and Chapman (2010), Strijbos et al. defined conceptual skills to include thinking skills, problem solving, creativity and information processing. People skills involve communication, teamwork and leadership, and thirdly, personal skills encompass competences such as critical reflection, lifelong learning, and social responsibility and ethics. Another proposal (Binkley et al. 2012) grouped ten 21st century skill into four groups: Ways of thinking (creativity and innovation, critical thinking, problem solving and decision-making, learning to learn and metacognition), Ways of working (communication and collaboration or teamwork), Tools for working (information and ICT literacy), and Living in the world (citizenship, life and career, and personal and social responsibility, including cultural awareness and competence). The latter grouping considers a somewhat broader scope of competences as it also encompasses digital literacy and agentic involvement as a responsible citizen; however, both proposals emphasize the generic nature of these competences.

In an OECD report (2013b), explaining necessary competences in global societies, general key competences were categorized into four major groups: Cognitive competences (communication, information processing, problem solving, learning and mathematics), Interpersonal competences (e.g., teamwork, cultural sensitivity), Intrapersonal competences (self-regulation, management, creativity/entrepreneurship), and Technological competences. Similarly to the categorizations of Strijbos and Binkley et al., these frame the individuals and their capacity development as self- 
standing, without an explicit relationship with the educational or professional culture where the competences are learned or utilized. To address this relationship, the work of Shaffer and colleagues (Shaffer 2006; Rupp, Gushta, Mislevy, \& Shaffer 2010) puts forth the concept of epistemic games to highlight the interplay between professional practices and generic competences: how students learn skills for thinking, acting, and interacting with others in productive ways while tackling complex profession-typical tasks around authentic problems.

An example of measuring group work skills is presented by Cumming, Woodcock, Cooley, Holland, and Burns (2015). Their research with the Groupwork Skills Questionnaire provided evidence on task group work skills (contributing to the management of group, and establishing roles) and interpersonal group work skills (contributing to the interpersonal dynamics of the group and emotional support). This ten-item questionnaire asks students to evaluate how often they are likely to employ specific group work skills. Other research can also be found that captures students' perceptions of their group work skills or attitudes towards collaboration (cf. Muukkonen et al. 2016). Broussard et al. (2007) measured task conflict, social interaction, psychological safety, problem-based learning attitudes, as well as synergistic knowledge development and explained the latter using the other measures. Lizzio and Wilson (2004) asked first year students to assess how well the items on a skills list characterised them, and their relevance for their present courses, future work, and personal interests. For our research purposes, these assessments have been carried out in a decontextualized manner that does not link self-assessment to competence-development during courses. 
In a broader sense, all these definitions group generic competences in a relatively similar way and emphasize their individual, collective, and technology-related aspects. Our understanding of competences in knowledge work and object-bound collaboration resonates with these aspects, but is especially based on the knowledge creation metaphor of learning and its design principles (Paavola et al. 2011).

\section{Educational practices supporting students' competences in knowledge work}

The models and practices for learning to deal with complexity (and hypercomplexity) are important outcomes of higher education (Barnett 2012). To foster the intended competences, the central pedagogical objectives, principles and methods should be explicitly stated and accompanied by outcomes assessment (Biggs 1999; Heijltjes, van Gog, Leppink, \& Paas 2014). When supporting students to become aware of the nature of knowledge within a discipline, it is imperative to encourage them to monitor and discuss their own understanding developments (Kember 2009; Kearney 2013; Lindblom-Ylänne 2006). Recent pedagogical approaches, accentuating competences required in knowledge-intensive societies, highlight dealing with authentic and open-ended problems (e.g., Muukkonen, Hakkarainen, \& Lakkala 2004;

Muukkonen \& Lakkala 2009), students developing epistemic agency (Scardamalia 2002), students' identity as knowledge contributors in learning communities (Wenger 1998), as well as technology-enhanced forms of participation and knowledge creation (Hakkarainen 2009) within educational practices. 
The theoretical approach in our research is the knowledge creation metaphor of learning (Paavola, Lipponen, \& Hakkarainen 2004; Paavola \& Hakkarainen 2009) which emphasizes the interaction between collective and individual efforts in working on shared objects. It is based on the iterative and sustained processes of object advancement, similar to work on epistemic objects in professional practices (Knorr Cetina 2001). Such collaboratively shared objects in educational setting may be for example reports, designs, plans or websites co-created by students. Compared to professional practices, these educational shared objects may be designed to be more compact and developed in subtasks. However, to retain the desired aspects of real-world complexity, it is important to consider how these objects could, nevertheless, exemplify the ill-defined, multidisciplinary, and evolving nature of epistemic objects and expert-like ways to advance them (Muukkonen et al. 2013).

Six design principles (Paavola et al. 2011) define the characteristics of pedagogical practices intended to promote students' knowledge work competences. These design principles (DP) guided the development of the CKP questionnaire.

DP1. Organizing activities around shared "objects". The first design principle emphasizes the epistemic and organizational aim to anchor the collective and individual efforts around a shared object. Developing a shared object takes place iteratively and requires both epistemic and regulative activities from groups through collective idea generation, sharing knowledge, critical evaluation, and planning process advancement. 
DP2. Supporting integration of personal and collective agency and work. The aim is to organize the learning process in such a way that students take responsibility for their own activities and learning but, importantly, also of the collective process and its outcomes (cf. collective cognitive responsibility by Scardamalia 2002, or shared epistemic agency by Damşa 2014). A pedagogical means to foster this integration is to create subtasks and milestones, which require a check on the advancement of individuals' contributions in relation to the team's shared object. Providing feedback and generating revised drafts are perceived as key factors in the integration of personal and collective efforts (see also Scardamalia \& Bereiter 2006).

DP3. Emphasizing development and creativity in working on shared objects through transformations and reflection. The epistemic objects of knowledge work are characteristically open-ended and evolving (Knorr Cetina 2001; Rheinberger 1997). This open-endedness poses challenges to creating a shared understanding. A way to support sense making and analysing the phenomena is to utilize various forms of documentation and representation of the phenomenon or object at hand as well as reflecting upon these transformational aims and processes.

DP4. Fostering sustained processes of knowledge advancement. The aim is to highlight ways to organize sustained processes of knowledge advancement within or across teaching units. It is motivating to work on shared objects that are subsequently used, e.g., outcomes are later used by customers, following student group building on prior course materials, or the students themselves using their results in later studies. 
DP5. Promoting cross-fertilization of knowledge practices and artefacts across communities and institution. Cross-fertilization refers to collaboration between various disciplines and organizations, for instance a university and a company or non-profit organization. The multidisciplinarity may manifest itself in various forms: students from various disciplines taking part in teamwork, teachers' complementary expertise, materials, tools, and expert-member professionals or customers participating in the course.

DP6. Providing flexible tools for developing artefacts and practices. Digital tools should mediate advanced forms of epistemic and regulative aspects of collaboration and co-creation; in addition, they should be typical for the professional practices. During multidisciplinary collaborations, students are challenged to learn to select and use collaboration tools efficiently.

\section{Research objectives}

The aim of the study was to investigate the development of students' collaborative knowledge work competences in light of pedagogical methods utilised during selected higher education courses. The study addresses the following research questions: 1) How did the students and lecturers evaluate the development of students' knowledge work competences during courses within two domains? 2) What was the relationship between the course practices and students' self-assessed competence development in two example courses?

\section{Method}




\section{Research contexts}

The data were collected from a research-intensive university and two applied sciences universities. The questionnaire was especially used in courses whose design involved student collaboration in teams and included digital technologies. The courses were also co-taught by four to seven lecturers, except for the largest course held by one lecturer. This meant that the courses included facilitation for teamwork and lecturers providing multiple areas of expertise. In the domain of media engineering, ten courses for first year students in a university of applied sciences were included. These courses were characterised by their intensity (students worked in all-day collaborations), integration of several subjects (e.g., communication skills, mathematics, physics, programming, and electronics) and project work. The newly revised first year curriculum for their media engineering program consists of four 15 ECTS courses, each designed for 25-30 students. Four life sciences courses were also included. Within another applied sciences university, the course was in a 15 ECTS module, designed for 31 first year students. Courses at the research university were two courses for 1st year students (54 and 144 students) and one for 3rd year students (36), consisting of 3, 5, and 5 ECTS respectively.

\section{Participants}

Students and lecturers in 29 higher education courses in media engineering and life sciences representing the STEM disciplines were invited to participate in the investigation. Altogether, 
589 students and 38 lecturers completed the questionnaire. There were only fourteen courses with at least nine student respondents and one lecturer respondent. These were included in this study, producing a data set of 274 students and 23 lecturers, with response rates of $56.6 \%$ and $39.4 \%$ respectively. The media engineering students $(\mathrm{N}=160, \mathrm{M}=22.2$ years, $\mathrm{SD}=3.0)$ were, on average, younger than the life science students $(\mathrm{N}=117, \mathrm{M}=24.8$ years, $\mathrm{SD}=6.7)$. There were more male $(n=125)$ than female $(n=35)$ students in media engineering, while in the life sciences there were fewer males $(n=31)$ than females $(n=83)$. Altogether, $43.8 \%$ of the students were female. The average age of the lecturers was 47.8 years $(\mathrm{SD}=7.4), 10$ of them were female and 12 male.

Two courses were chosen for closer analysis to examine the relationship between pedagogical practices and the students' and lecturers' evaluation of competence learning. These courses were an engineering course Objects from an applied university (responses from 22 students and one lecturer) and a biology course, Plant sciences from a research university (responses from 54 students and one lecturer). These courses were chosen because they both included a specified pedagogical design that involved students working as experts with the studied knowledge, but were also typical for their institutions in their teaching arrangements.

\section{Questionnaire and course data}

The Collaborative Knowledge Practices Questionnaire, CKP (Muukkonen et al. 2016), has been designed to evaluate self-assessed competence-development for courses that use group work as their instructional method. Theoretically, the item construction was based on the design 
principles of the knowledge creation metaphor of learning (Paavola et al. 2011). Our aim in designing the instrument was to situate evaluation within a specific course, but to examine domain-generic competences. Therefore, our research approach attempts to generate feedback for the students, lecturers and the pedagogical designers on course-specific outcomes in a format that can be compared across courses and examined independently from course contents.

The questionnaire consisted of 27 items loading on seven factors: S1 Learning to collaborate on shared objects (DP1), S2 Integrating efforts in collaborative working (DP2), S3 Development through feedback (DP2 and DP3), S4 Persistent development of knowledge objects (DP3 and DP4), S5 Understanding various disciplines and practices (DP5), S6 Interdisciplinary collaboration and communication (DP5), and S7 Learning to exploit technology (DP6). Scale example items and Cronbach's alphas are presented in Table 1. The reliability of the scales was considered to be satisfactory.

Table 1. Scales of the Collaborative Knowledge Practices questionnaire

\begin{tabular}{|l|l|l|}
\hline $\begin{array}{l}\text { Scale } \\
\text { Learning of competences }\end{array}$ & $\begin{array}{l}\text { Alpha } \\
\text { (items) }\end{array}$ & $\begin{array}{l}\text { Example items } \\
\text { During the course I have learned... }\end{array}$ \\
\hline $\begin{array}{l}\text { Learning to collaborate on } \\
\text { shared objects (S1) }\end{array}$ & $.79(4)$ & $\begin{array}{l}\text { to coordinate the development of products } \\
\text { (e.g., plans, reports, models) together with } \\
\text { others. } \\
\text { to develop ideas further together with others. }\end{array}$ \\
\hline $\begin{array}{l}\text { Integrating efforts } \\
\text { collaborative working (S2) }\end{array}$ & $.75(4)$ & $\begin{array}{l}\text { to accomplish challenging tasks in } \\
\text { collaboration with others. }\end{array}$ \\
\hline
\end{tabular}




\begin{tabular}{|l|l|l|}
\hline & $.73(4)$ & $\begin{array}{l}\text { to understand how important the expertise of } \\
\text { others is when developing products. }\end{array}$ \\
\hline $\begin{array}{l}\text { Development through } \\
\text { feedback (S3) }\end{array}$ & $\begin{array}{l}\text { to receive feedback on my products for } \\
\text { developing them further. } \\
\text { to understand the value of commenting work } \\
\text { in progress. }\end{array}$ \\
\hline $\begin{array}{l}\text { Persistent development of } \\
\text { knowledge-objects (S4) }\end{array}$ & $\begin{array}{l}\text { to work on products that are used later by } \\
\text { others or myself. } \\
\text { to evaluate how much effort is needed to } \\
\text { develop a product. }\end{array}$ \\
\hline $\begin{array}{l}\text { Understanding various } \\
\text { disciplines and practices } \\
\text { (S5) }\end{array}$ & $.72(4)$ & $\begin{array}{l}\text { about the practices of work-life experts. } \\
\text { the practices of people with different kinds of } \\
\text { expertise. }\end{array}$ \\
\hline $\begin{array}{l}\text { Interdisciplinary } \\
\text { collaboration and } \\
\text { communication (S6) }\end{array}$ & $.80(4)$ & $\begin{array}{l}\text { to ask questions relating to the practices of } \\
\text { another field. } \\
\text { to present my expertise to representatives of } \\
\text { another field. }\end{array}$ \\
\hline $\begin{array}{l}\text { Learning to exploit } \\
\text { technology (S7) }\end{array}$ & $\begin{array}{l}\text { to use technology to advance collaborative } \\
\text { to develop products collaboratively by using } \\
\text { technology. }\end{array}$ \\
\hline
\end{tabular}

Students were asked to evaluate how well each statement corresponds to what they had learned during the course. "During the course I have learned..." e.g., "to develop ideas further together with others" and "to present my expertise to representatives of another field". The statements 
were rated on a five-point Likert scale ranging from 1 (strongly disagree) to 5 (strongly agree) as well as "Not applicable to this course" $(0)$.

The lecturers responded to the same questionnaire items at the end of the course, but their instruction was to answer: "In my opinion, students learned during the course...". In addition, the lecturers described course practices in answers to open-ended questions on course objectives, group formation, temporality of teaching and studying arrangements, nature of tasks, work produced by students, assessment, and reflections on the implementation.

\section{Procedure}

Students and teachers were asked to answer the questionnaire electronically at the end of their course, and participants who gave their informed consent were included in the study. The researchers provided the lecturers with links to the e-questionnaire and a description of the research procedure and objectives. The lecturers forwarded the e-questionnaire to their students and encouraged their participation. An overview report with responses from students and lecturer(s) was delivered to the lecturers at the end of the course, to be used as material for reflection and course development.

\section{Data analysis}


Questionnaire data from fourteen courses were screened; the responses of ten students were excluded, either because of missing data or too many (ten or more) "not applicable" responses to items. We replaced "not applicable" responses with "strongly disagree" in the scale means to aid interpretation of the data. The challenge with the Likert scale in the data was that with certain items and scales there were fairly many "not applicable to this course" responses; these were appropriate answers in view of the course's pedagogical practices and intended learning outcomes. Therefore, if there were no such learning activities, then providing a "not applicable" response would translate to "strongly disagree". Using an alternative that was more extreme than "strongly disagree" would have biased the results.

We carried out an explorative GEOMIN rotated factor analysis with the Mplus statistical package (version 7.2; Muthén \& Muthén 1998-2011) including all the students $(\mathrm{N}=589)$. This provided a solution reported in Muukkonen et al. (2016). The GEOMIN rotation is recommended when factor indicators have substantial loadings on more than one factor and the rotation is oblique (Browne 2001; Muthén \& Muthén 1998-2011). In this data, all factors have rather high correlations, and our preliminary analysis showed that the GEOMIN solution was the most unequivocal to interpret. Based on these factor loadings, we constructed the seven scales used in the present study. One-sample t-tests were calculated separately for media engineering and life science courses to investigate whether students' scores differ from the lecturers' mean (consensus) scores for each scale. The groups were not compared statistically because the aim was not to study the differences between the domains but rather the differences between students' and teachers' responses within domains. 
To answer the second research question, students' and lecturers' questionnaire data from two example courses were examined in relation to the pedagogical practices informed by the lecturers' answers to open-ended questions. An overview of the course practices was constructed in a descriptive manner based on the characteristics of teaching arrangements (e.g., frequency of face-to-face teaching or guidance, type of assignments), intensity of students' activities (e.g., once a week or full days), objectives and expected outcomes of group work, formative and peer feedback, integration of several subjects, multidisciplinarity of participating teachers and students, collaboration with external experts, and use of digital technology. This description was used to make comparisons between the two courses in terms of reported competencedevelopment.

\section{Results}

\section{Comparison of students' and lecturers' evaluations of students' knowledge work competence- development during the courses}

A comparison of students' self-assessed and lecturer-assessed competence-development in two domains is presented in Table 2. In the media engineering courses, no differences between lecturers' and students' scores were found with one-sample t-test on four scales: Integrating efforts in collaborative working (S2), Development through feedback (S3), Persistent development of knowledge objects (S4) and Learning to exploit technology (S7). For Learning to 
collaborate on shared objects (S1) in both domains and scales S2, S3, S4, S7 in life sciences, the lecturers evaluated the students' competence-development higher than students assessed their own learning. However, in media engineering the scales Interdisciplinary collaboration (S6) and Understanding various disciplines (S5) generated outcomes in the opposite direction; students responded statistically higher. In life sciences there were no mean differences on these scales between teachers and students. Except for these two scales, the scores reported by students were quite high, indicating that these types of competences were indeed learned during the courses.

Table 2. Scale score means, standard deviations and one sample t-tests comparing student responses to lecturer consensus in two domains.

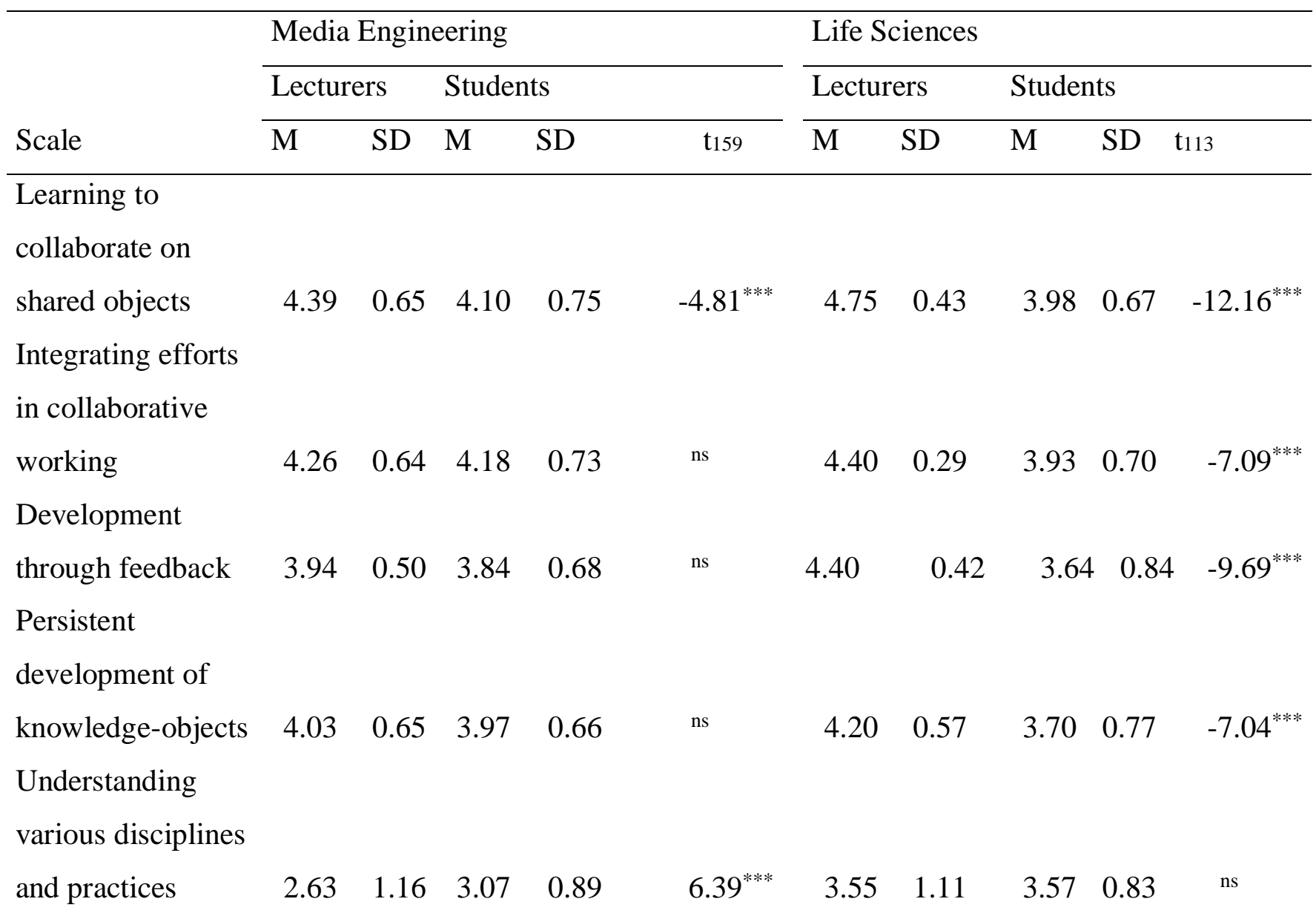


Interdisciplinary

collaboration and

communication

$2.31 \quad 1.23 \quad 2.66 \quad 1.06$

$4.12^{* * *}$

$3.07 \quad 1.52$

$3.08 \quad 0.96$

ns

Learning to exploit

technology

$\begin{array}{llll}4.11 & 0.55 & 4.03 & 0.68\end{array}$

ns

$4.00 \quad 0.68$

$3.48 \quad 0.93$

$-5.96^{* * *}$

${ }^{*} \mathrm{p}<.05 ;{ }^{* *} \mathrm{p}<.01 ;{ }^{* * *} \mathrm{p}<.001 ; \mathrm{ns}=$ not statistically significant.

$\mathrm{M}=$ Mean, $\mathrm{SD}=$ Standard deviation .

\section{Relationship between evaluated competence-development and course practices: examination of two courses}

The questionnaire items examined competence learning during a specific course, and the students' evaluations are context-bound. Therefore, it is important to examine the questionnaire answers in relation to the types of activities students were engaged in, because the activities and assignments probably have an impact on the types of competences students cultivate during the course. To describe this course-related variation, we took a closer look at two HE courses: the engineering course "Objects" and the biology course "Plant sciences". Both courses were bachelor-degree-program, first period, first semester courses. Figure 1 shows the scaled answers of students and lecturers for the two courses. 


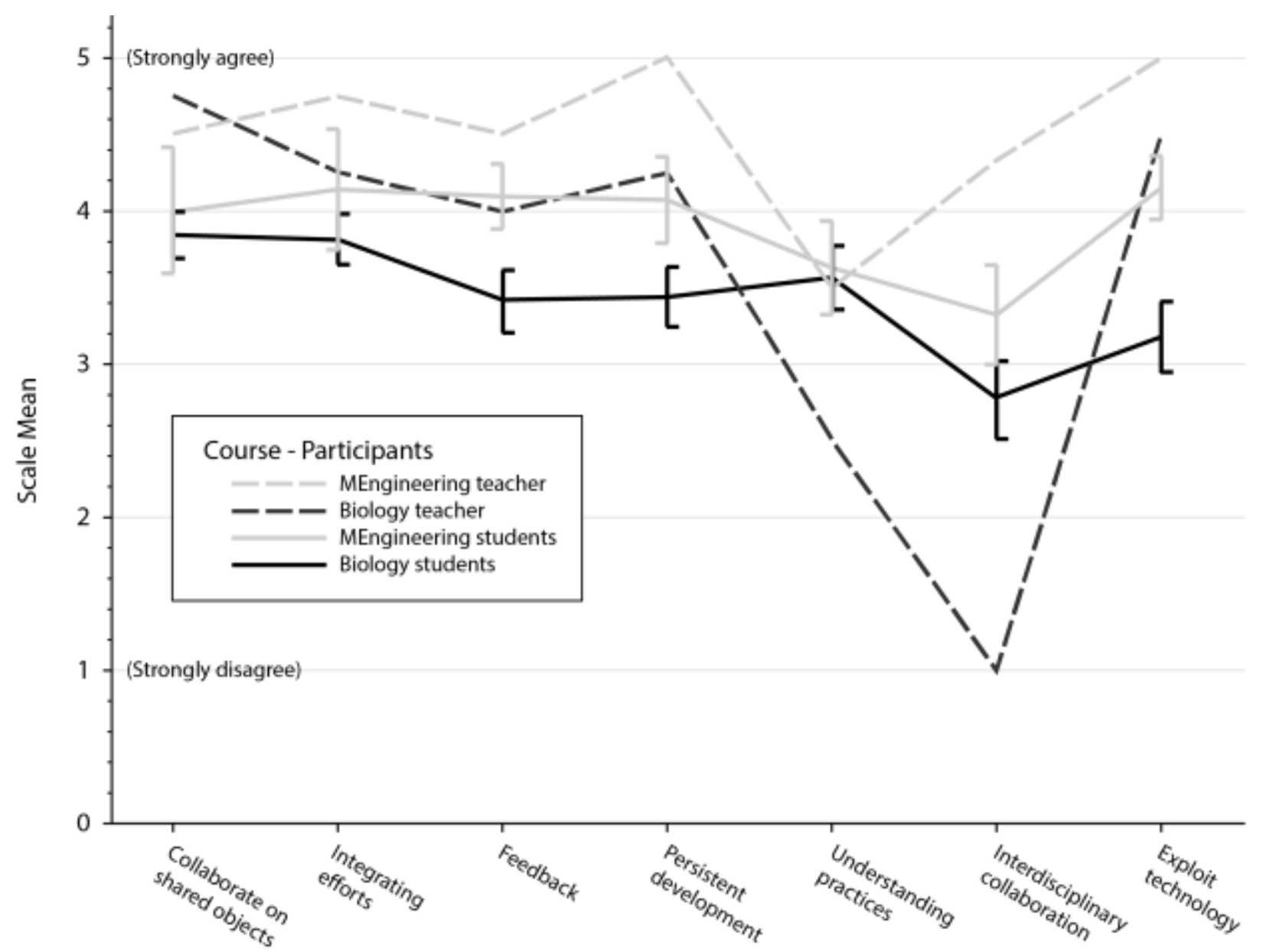

Figure 1. Students' and teacher' responses from two courses

The lecturers had, in these two courses, systematically evaluated the learning of competences higher than students on scales 1-4 and 7. The level of students' self-reported competence learning was generally higher in the engineering than in the biology course. The engineering course was more intensive, it included all day studying for eight weeks, and was mainly projecttype teamwork. It was a Java object-oriented programing course. Students designed and programmed a Lego Mindstorms robot in project teams. In the biology course, students were acquainted with research practices through visits to a plant museum and botanical gardens, and 
they had a group task to update the Bank of Finnish Terminology in Arts and Sciences (http://tieteentermipankki.fi/) as if they were experts in the field. The biology course was more lecture-based and it only had one weekly meeting for seven weeks and multiple short-term group assignments, therefore it lacked the intense collaboration of the engineering course. This may have had an effect on the extent of the experienced competence-development, particularly iterative development through feedback and persistent development of knowledge objects.

Both courses introduced students to professional ways of working. The scoring by students and lecturers is very similar in media engineering for S5, Understanding various disciplines and practices. The biology course teacher gave low evaluations for scales S5 and S6. Students in both courses gave the lowest scores for S6 Interdisciplinary collaboration and communication. Neither of the courses included intensive collaboration with external experts nor interdisciplinary teamwork. However, teaching of the engineering course integrated several subjects and lecturers representing multiple domains, which might explain the higher scores given by both students and lecturers for that course. The difference between the scores given by the lecturer and students in the biology course is notew orthy. Perhaps the students considered the contribution of multiple lecturers and visits to professional institutions outside the university as extending possibilities for interdisciplinary collaboration. The lecturer might have focused on actual interdisciplinary teamwork in answering the items.

The largest difference between the scores given by students in the two courses was for S7 Learning to exploit technology. Understandably, technology was used more extensively in the 
engineering course, because technology was both a tool and the content to be learnt. The lecturer of the biology course had quite high evaluations for the students' learning of technical competences compared to the students' ratings; possibly the students were not accustomed to the technical tools used in the course and would have needed more support and practice than provided to feel that their digital competences had improved significantly.

\section{Discussion}

\section{Difference in competence-evaluation between lecturers and students}

A comparison of findings on students' self-assessed and lecturer-assessed competencedevelopment provided evidence of lecturers expecting and claiming more learning had taken place than the students. Within the life sciences domain the differences were even more pronounced than for media engineering. The lecturers' high ratings may relate to the fact that these courses stood apart from typical higher education courses as they involved demanding assignments with small group collaboration, and thus, were expected to be particularly educative on those dimensions. Further, the difference in scores between lecturers and students may reflect the fact that the lecturers assessed general student learning and the students assess their personal experiences. The lecturers might more easily notice well-functioning student teams, good learning results and outcomes of the work processes, whereas the students assess their learning primarily as individuals and members of a certain team, thus their responses might vary extensively depending on the team. If the teamwork and results were not as good as the students 
have expected, they might assess their competence-development more critically. This might complicate the interpretation of course-level data. A solution could be to include group level in the analysis.

Only in the two scales that addressed competences related to cross-fertilization of practices, namely Understanding various disciplines (S5) and Interdisciplinary collaboration and communication (S6), were the media engineering lecturers' scores lower. It appears that the lecturers understood this issue as more confined to hands-on interdisciplinary work, and were justifiably critical, while the students in media engineering interpreted it more broadly. Generally during the courses, the students were not engaged in hands-on work with students in different domains except for one more advanced life science course. The lecturers themselves had different expertise areas, and the students were working on course assignments that included multiple perspectives and expert practices (S5) or teamwork integrating various areas of expertise and some contacts with work-life professionals (S6).

\section{Course practices reflected in students' assessments}

The descriptive comparison of two courses and the student assessments of their learning during them were in line with each other, i.e. the questionnaire results were understandable when they were compared with the pedagogical practices of the courses. The intensity of activities and type of assignments had an impact on the competence-learning students reported. More intense collaboration was related to higher ratings for learning about the feedback practices and the 
iterative nature of development efforts. Both courses had assignments that simulated multiple aspects of authentic professional tasks; this produced similar ratings on learning to collaborate on shared objects and understanding various disciplines and practices. However, the collaboration itself was not interdisciplinary, which resulted in lowest scores on that scale. Finally, competences in the use of technology were highlighted in the media engineering course, which included a rich use of digital technology.

\section{Implications for assessment}

The results showed that it is valuable to combine survey data with qualitative data on course objectives and practices to build a multi-fold understanding of the interplay between pedagogical methods and competence learning. The lecturers appeared to anticipate that the pedagogical practices worked more effectively than they actually did. Overall, it is challenging to evaluate collaboration, because it is not only dependent on student's individual efforts, but is always linked to a specific team of collaborating students. Students, like lecturers, might be accustomed to assessing their learning quite traditionally from the viewpoint of domain-specific course content, and have little experience in assessing domain-general knowledge work competences. Further, students are still learning these competences, and might find it difficult to direct or coregulate their efforts towards the intended aims (cf. Järvelä et al. 2013). Even if teamwork succeeds, it might have involved phases that students found challenging, laborious, or confusing (Muukkonen et al. 2010). This could make them question their competences in collaborative activities. Therefore, students should be repeatedly exposed to persistent object-oriented work in 
different teams and contexts, enabling them to learn these competences through multiple processes and experiences. To help all teams succeed, it is essential to monitor team level progress (for instance through learning analytics embedded in digital tools), provide scaffolding for struggling teams, and model efficient teamwork practices.

The CKP questionnaire provides a tool to grasp domain-general competences related to collaboration and knowledge work. It is to be used in combination with other indicators or forms of assessment, e.g., lecturers' assessments of group outcomes and processes, peer and selfassessment (Falchikov \& Boud 1999; Kearney 2013), and documentation of course practices by lecturers or researchers. These complementary measures provide a diverse scope for evaluating course learning outcomes.

For students, gaining meta-level understanding of their own competences is critical for employability and lifelong-learning (Clark 2012; Falchikov 2005). Similarly, understanding the dynamics of shared agency is vital for developing competences for collective knowledge creation and co-design. Both types of understanding support work in continuously changing professional contexts.

As Moore and Morton (2015) argued, higher education should provide exposure to a range of experience and tasks that give graduates tools to mould their disciplinary knowledge in expert ways. We have attempted to explicate the collaborative dimensions of generic competences. We propose that students should learn these during HE so they can utilise their domain-specific 
expertise effectively both during their studies and their future work lives. To ensure a continued trajectory of learning knowledge work competences, degree programs should systematically ask students and lecturers to evaluate the learning of generic competences. Following students through their transitions to the workplace and re-measuring these competences in those contexts is recommended. Continued research is needed to identify the types of educational practices and elements in course and curriculum design that teach knowledge work and object-bound collaboration competences, and to explicate the potentials of university-industry collaboration in education.

\section{Acknowledgements}

The study was partially supported by the EU-funded KNORK project (543154-LLP-1-2013-1FI-KA3-KA) and ARONI Research Project (285806) funded by the Academy of Finland. We are very grateful for the students and teachers who volunteered to participate and for the assistance of Pekka Lahti-Nuuttila in preparing the paper.

\section{References}

Banta, T \& Pike G 2012, 'Making the case against - One more time Commentary on R.

Benjamin, The Seven Red Herrings About Standardized Assessments in Higher Education’, National Institute for Learning Outcomes Assessment, viewed 6 June 2015, http://learningoutcomesassessment.org/documents/HerringPaperFINAL.pdf 
Barnett, R 2012, 'Learning for an unknown future', Higher Education Research \& Development, vol. 31, no.1, pp. 65-77.

Bereiter, C 2002, Education and mind in the knowledge age, Erlbaum, Hillsdale.

Biggs, J 1999, 'What the student does: teaching for enhanced learning', Higher Education Research \& Development, vol. 18, no. 1, pp. 57-75.

Binkley, M, Erstad, O, Herman, J, Raizen, S, Ripley, M, Miller-Ricci, M \& Rumble, M 2012, 'Defining twenty-first century skills', in P Griffin, B McGaw \& E Care (eds.), Assessment and teaching of 21 st century skills, Springer.

Broussard, SR, La Lopa, JM \& Ross-Davis, A 2007, 'Synergistic knowledge development in interdisciplinary teams', Journal of Natural Resources \& Life Sciences Education, vol. 36, pp. $129-133$.

Browne, MW, 2001, 'An overview of analytic rotation in exploratory factor analysis', Multivariate Behavioral Research, vol. 36, 111-150.

Clark, I 2012, 'Formative assessment: Assessment is for self-regulated learning', Educational Psychology Review, vol. 24, pp. 205-249.

Cumming, J, Woodcock, C, Cooley, SJ, Holland, MJG \& Burns, VE 2015, 'Development and validation of the groupwork skills questionnaire (GSQ) for higher education', Assessment \& Evaluation in Higher Education, vol. 40, pp. 988-1001.

Damşa, CI, Kirschner, PA, Andriessen, JEB, Erkens, G \& Sins, PHM, 2010, 'Shared epistemic agency: An empirical study of an emergent construct', Journal of the Learning Sciences, vol. 19, pp. $143-186$. 
Damşa, CI 2014, 'The multi-layered nature of small-group learning: Productive interactions in object-oriented collaboration', International Journal of Computer-Supported Collaborative Learning, vol. 9, pp. 247-281.

Falchikov, N 2005, Improving assessment through student involvement, Routledge, New York.

Falchikov, N \& Boud, D 1989, 'Student self-assessment in higher education: A meta-analysis', Review of Educational Research, vol. 59, no. 4, pp. 395-430.

Greiff, S, Wüstenberg, S, Csapó, B, Demetriou, A, Hautamäki, J, Graesser, A \& Martin, R 2014, 'Domain-general problem solving skills and education in the 21 st century', Educational Research Review, vol. 13, pp. 74-83.

Hakkarainen, K 2009, 'A knowledge-practice perspective on technology-mediated learning', International Journal of Computer-Supported Collaborative Learning, vol. 4, pp. 213-231.

Hakkarainen, K, Palonen, T, Paavola, S \& Lehtinen, E 2004, Communities of networked expertise: Professional and educational perspectives. Advances in Learning and Instruction Series, Elsevier, Amsterdam.

Halpern, DF 2014, Thought and knowledge, 5th edn, Psychology Press.

Heijltjes, A., van Gog, T., Leppink, J., \& Paas, F. (2014). Improving critical thinking: Effects of dispositions and instructions on economics students' reasoning skills. Learning and Instruction 29, 31-42.

Jalonen, S, Lakkala, M \& Paavola, S 2011, 'Investigating knowledge creation technology in an engineering course', Computers \& Education, vol. 57, pp. 1930-1942. 
Järvelä, S, Järvenoja, H, Malmberg, J \& Hadwin, AF 2013, 'Exploring socially shared regulation in the context of collaboration', Journal of Cognitive Education and Psychology, vol. 12, pp. 267-286.

Karlgren, K 2012, 'Trialogical design principles as inspiration for designing knowledge practices for medical simulation training', in A Moen, AI Mørch \& S Paavola (eds.), Collaborative Knowledge Creation: Practices, Tools, and Concepts, Rotterdam, Netherlands: Sense Publishers.

Kearney, S 2013, 'Improving engagement: The use of' Authentic self-and peer-assessment for learning' to enhance the student learning experience', Assessment \& Evaluation in Higher Education, vol. 38, no. 7, pp. 875-891.

Kember, D, 2009, 'Nurturing generic capabilities through a teaching and learning environment which provides practice in their use', Higher Education, vol. 57, pp. 37-55.

Klusek, L \& Bernstein, J 2006, 'Information literacy skills for business careers: Matching skills to the workplace, Journal of Business \& Finance Librarianship, vol. 11, pp. 3-21.

Knorr Cetina, K 2001, 'Objectual practice', in TR Schatzki, K Knorr Cetina \& E von Savigny (eds.), The practice turn in contemporary theory, Routledge, London and NY.

Kosonen, K, Muukkonen, H, Lakkala, M \& Paavola, S 2012, 'Product development course as a pedagogical setting for multidisciplinary professional learning', in A Moen, A Mørch \& S Paavola (eds.), Collaborative Knowledge Creation: Practices, Tools, Concepts, Rotterdam, Netherlands: Sense Publishers. 
Lakkala, M, Muukkonen, H, Paavola, S \& Hakkarainen, K 2008, 'Designing pedagogical infrastructures in university courses for technology-enhanced collaborative inquiry', Research and Practice in Technology Enhanced Learning, vol. 3, no. 1, 33-64.

Lindblom-Ylänne, S 2006, 'Enhancing the quality of teaching in higher education in Finland: The case of the University of Helsinki', New Directions for Higher Education, vol. 133, pp. 63-71.

Lizzio, A \& Wilson, K 2004, 'First-year students' perceptions of capability', Studies in Higher Education, vol. 29, pp. 109-128.

Moore, T \& Morton, J 2015, 'The myth of job readiness? Written communication, employablilty, and the "skills gap" in higher education', Studies in Higher Education, 42(3), 591-609, DOI: $10.1080 / 03075079.2015 .1067602$

Muthén, L \& Muthén, BO 1998-2011, Mplus users guide, 7th edn, Muthén \& Muthén, Los Angeles, CA.

Muukkonen, H, Lakkala, M. Toom, A, Lahti-Nuuttila, P, Karlgren, K \& Ilomäki, L 2016, Collaborative Knowledge Practices Questionnaire for collaboration courses in higher education, Manuscript in preparation.

Muukkonen, H, Kosonen, K, Marttiin, P, Vesikivi, P, Kaistinen, J \& Nyman, G 2013, 'Pedagogical design for knowledge creation in customer projects', Knowledge Management \& E-Learning, vol. 5, no. 3, pp. 278-297.

Muukkonen, H., Lakkala, M., Kaistinen, J. \& Nyman, G. 2010. Knowledge creating inquiry in a distributed project management course. Research and Practice in Technology-Enhanced Learning, 5, 73-96. DOI: 10.1142/S1793206810000827 
Muukkonen, H \& Lakkala, M, 2009, 'Exploring metaskills of knowledge-creating inquiry in higher education', International Journal of Computer Supported Collaborative Learning, vol. 4, no. 2, pp. 187-211.

Muukkonen, H, Lakkala, M \& Hakkarainen, K 2005, 'Technology-mediation and tutoring: how do they shape progressive inquiry discourse?' The Journal of the Learning Sciences, vol. 14, no. 4 , pp. $527-565$.

Muukkonen, H, Hakkarainen, K \& Lakkala, M 2004, 'Computer-mediated progressive inquiry in higher education', in TS Roberts (ed.), Online collaborative learning: Theory and practice, Hershey PA: Information Science Publishing.

Nätti, J, Anttila, T \& Tammelin, M 2012, 'Knowledge work, working time, and use of time among Finnish dual-earner families - does knowledge work require the marginalization of private life?' Journal of Family Issues, vol. 33, pp.295-315.

OECD 2013a, Assessment of higher education learning outcomes. AHELO Feasibility study report, vol. 3 - Further insights, viewed 24 June 2015, http://www.oecd.org/edu/skills-beyondschool/AHELOFSReportVolume3.pdf

OECD 2013b, The Survey of Adult Skills: Reader's Companion, OECD Publishing, viewed 24 June 2015, http://dx.doi.org/10.1787/9789264204027-en

Paavola, S, Lipponen, L \& Hakkarainen, K 2004, 'Models of innovative knowledge communities and three metaphors of learning', Review of Educational Research, vol. 74, no. 4, pp. 557576.

Paavola, S \& Hakkarainen, K 2009, 'From meaning making to joint construction of knowledge practices and artefacts - A trialogical approach to CSCL', in C O'Malley, D Suthers, P 
Reimann \& A Dimitracopoulou (eds.), Computer supported collaborative learning Practices:

Proceedings of the 9th international conference of Computer Supported Collaborative

Learning, vol. 1, International Society of the Learning Sciences.

Paavola, S, Lakkala, M, Muukkonen, H, Kosonen, K \& Karlgren, K 2011, 'The roles and uses of design principles for developing the trialogical approach on learning', Research in Learning Technology, vol. 19, no. 3, pp. 233-246.

Rheinberger, HJ 1997, Toward a history of epistemic things: Synthesizing proteins in the test tube, Stanford University Press, Stanford, CA.

Rupp, AA, Gushta, M, Mislevy, RJ \& Shaffer, DW 2010, 'Evidence-centered design of epistemic games: Measurement principles for complex learning environments', The Journal of Technology, Learning and Assessment, vol. 8, no. 4, viewed 15 April 2015, http://ejournals.bc.edu/ojs/index.php/jtla/issue/view/162

Sadler, DR 2009, 'Transforming holistic assessment and grading into a vehicle for complex learning', in G Joughin (ed.), Assessment, learning and judgement in higher education, Springer.

Scardamalia, M 2002, 'Collective cognitive responsibility for the advancement of knowledge', in B Smith (ed.), Liberal education in a knowledge society, Chicago, IL: Open Court.

Scardamalia, M \& Bereiter, C 2006, 'Knowledge building: Theory, pedagogy, and technology', in K Sawyer (ed.), Cambridge Handbook of the Learning Sciences, Cambridge University Press.

Shaffer, DW 2006, 'Epistemic frames for epistemic games', Computers and Education, vol. 46, pp. 223-234. 
Shavelson, RJ 2010, Measuring college learning responsibly: Accountability in a new era, Stanford University Press.

Strijbos, J, Engels, N \& Struyven, K 2015, 'Criteria and standards of generic competences at bachelor degree level: A review study', Educational Research Review, vol. 14, pp. 18-32.

Wenger, W 1998, Communities of practice: Learning, meaning, and identity, Cambridge University Press.

Young, J \& Chapman, E 2010, 'Generic competency frameworks: A brief historical overview', Education Research and Perspectives, vol. 37, pp. 1-24. 